\title{
Analysis of Financial Reporting as a Method of Detection of the Facts of Falsification
}

\author{
Yuriy I. Sigidov ${ }^{*}$ Marina A. Korovina, Natalya S. Vlasova \\ Kuban State Agrarian University, Krasnodar 350044, Russian Federation \\ *Corresponding author.Email: tbu_kuban@mail.ru
}

\begin{abstract}
Financial Reporting shows the status of assets, financial results, structure of capital and cash flow of the economic entity. The opinions and decisions of vested interests depend on how reliable is the data depicted in reporting. Often firm managers use a variety of measures to «sugarcoat» Financial Reporting and affect decisions of vested interests. Falsification of Financial Reporting misleads investors, creditors and other entities. That is why the detection of falsification of Financial Reports is the main task not only of administration but also of internal controlling branches. The goal of this research is to develop a procedure based on the analysis of rate variation of financial ratios for the detection of Financial Reporting falsifications. From the set goal, the next tasks were found - a sample of financial rations traditionally used in Russia are observed carefully on variations of rates where proof of falsification can be stated; make a calculation of coefficients using the Financial Reports on a given sample of firms during the specified period; analyze the rates of calculated ratios and detect the availability of falsifications in given reports. A novelty of the research is based on the development of a method using financial indexes applied in the Russian reporting practice.
\end{abstract}

Keywords: financial reporting, falsification, detection, analysis

\section{INTRODUCTION}

Financial Reporting is a barely unique source of information for analysis of the main financial indexes in a firm's operation. A balance sheet shows the composition, structure and dynamic of assets, how they were formed and gives a chance to analyze solvency and financial stability. Based on the Income Statement, such indexes as Profitability Index, Efficiency of Resources and Turnover of Assets are evaluated [1,2]. Annexes to the accounts detail the key figures of the two main reports, showing changes in fixed assets, cash flows, composition and structure of fixed assets, intangible assets, inventories, receivables and credit liabilities, as well as other types of assets and liabilities. That is why an appraisal of the reliability of reporting data is the top priority for analytical and accounting teams in a firm. Falsification of Financial Reporting misleads investors, creditors and other entities. Based on this issue detection and prevention of Financial Reporting falsification is a very important point.

There are two highlighted types of detection of falsification of reporting data based on the analysis of accounting indicators.

Using the first one - the analysis of Cash Flow is conducted [3]. Net of Cash Flow is compared with Net Profit showed in the Income Statement. A big gap between these two indexes proves the falsification of Financial Reporting. The second method has the name of the «Beneish' model» invented by M. Daniel Beneish [4]. The foundation of this method is represented by the analysis of financial coefficients calculated using clauses of the Balance Sheet and

the Income Statement; and again, in case of difference more than 1 between them, a chance of falsification takes place. For the analyses, the next ratios are applied.

- GMI - Index of Profitability of Sales by Gross Profit;

- SGI - Revenue Growth Rate;

- DSRI - Index of Daily Sales of Account Receivable;

- SGAI - Commercial and Administrative Expenditures Index;

- AOI - Assets Quality Index;

- TATA - Accruals to Assets;

- DEPI - Amortization Index;

- LVGI - Financial Independence Coefficient [5, 6, 7].

M. Beneish proposed to group given rates in the integrated index $\ll \mathrm{M}$-score»:

$$
\begin{gathered}
\text { M-score }=-4,84+0,92 \times \text { DSR }+0,528 \times \text { GMI }+ \\
+0,404 \times \text { AQI }+0,892 \times \text { SG }+0,115 \times \text { DEPI }+ \\
+0,172 \times \text { SGAI }+4,679 \times \text { TATA }+0,327 \times \\
\times \text { LVGI }
\end{gathered}
$$

According to M. Beneish, an exceed of M-score -2,22 proves that Revenue is falsified. Applicability of the given model in Russia is associated with several difficulties. Firstly, the difference between Russian and Western accounting models, a use of variety financial indexes not common in Russia. 
Secondly, the model should be adopted to the specifics of different industries.

Thirdly, for detection of falsification factors a more detailed financial analysis is required. As was said, a novelty of the research is based on the development of a procedure for detection of financial falsification through improvements of the «Beneish' model» adding to it the traditional rate of coefficients of economic analysis.

The input of authors consists of a description of the model for detection financial falsification and its testing based on Financial Reporting of agrarian firms.

The goal of this research is to develop a procedure based on the analysis of rate variation of financial ratios for the detection of Financial Reporting falsifications:

- a sample of financial rations traditionally used in Russia are observed carefully on variations of rates where proof of falsification can be stated;

- calculate coefficients using the Financial Reports on a given sample of firms during the specified period;

- analyze the rates of calculated ratios and detect the availability of falsifications in given reports.

\section{MATERIALS AND METHODS}

The model proposed by us is based on the growth rates of some absolute and relative indicators. A divergence of growth rates from 1 either increasing or reducing potentially shows the evidence of falsified reports.

Let's consider the given indexes:

1. The Growth Rate of Revenue. Revenue is compared between the current and accounting year.

$$
\mathrm{GRoR}=\frac{\mathrm{RfS} 1}{\mathrm{RfS} 0} ;
$$

where, GRoR - Growth Rate of Revenue;

$\mathrm{RfS}_{1}-$ Revenue from Sales of the accounting period;

$\mathrm{RfS}_{0}$ - Revenue from Sales of the previous period.

2. The Growth Rate of Assets Quality is defined by the next equation:

$$
G R o A Q=\frac{(A Q 1-G A 1-R V F A 1) \div A Q 1}{(A Q 0-G A 0-R V F A 0) \div A Q 0} ;
$$

where, GRoAQ - the Growth Rate of Assets Quality;

A - total assets at the end of the period;

GA- the number of current assets at the end of the period;

RVFA - the residual value of fixed assets at the end of the period.

In case if the given index exceeds 1, the excess of growth in non-current assets outweighs the value of total assets. If in this case the growth of fixed assets in value is not observed, then a firm unreasonable capitalizes its expenses.

3. The Growth Rate of the share of Gross Profit in Revenue.
The Growth Rate of the share of Gross Profit and Revenue should not considerably differ what confirms the reliability of financial information.

This is defined by the next equation:

$$
\text { GRosGPR }=\frac{(G P 1-\operatorname{CoS} 1) \div G P 1}{(G P 0-\operatorname{CoS} 0) \div G P 0}
$$

where, GRosGPR - the Growth Rate of the share of Gross Profit in Revenue;

CoS1 - costs of sales of the accounting period;

CoS0 - costs of sales of the previous period.

4. The Growth Rate of Turnover of Account Receivable having stable conditions should not change significantly. It is defined by the next definition:

$$
\text { GRoToAR }=\frac{A R 1 \div G P 1 \div 365}{A R 0 \div G P 0 \div 365}
$$

where, GRoT is the growth rate of turnover of account receivable

$\mathrm{AR}$ - account receivable on the end of the period

5. The Growth Rate of shares of Depreciation Assurances also should not volatile in normal conditions. It is defined according to the next equation:

$$
G R S D A=\frac{D A 1 \div I C 1}{D A 0 \div I C 0}
$$

GRsDA - the growth rate of depreciation assurances DA - the sum of depreciation assurances IC - the initial costs of fixed assets at the end of period

6. The Growth Rate of shares of Expenses in Revenue is defined by the equation:

$$
G R S E R=\frac{R 1 \div G P 1}{R 0 \div G P 0}
$$

where, GRsE - the growth rate of shares of expenses in revenue;

$\mathrm{R}$ - the cost of sales, including sales expenses.

The above-mentioned index has to be compared with the Growth Rate of Revenue. In case of considerable divergence, a suspicion of distortion arises either in Revenue or Costs of Sales.

\section{RESULTS}

Now we will count the Growth Rates of above-described indexes on the example of three economic entities in Krasnodarskii Krai' at the period from 2014 until 2018. The results of the calculations are represented on the figures1-5. 


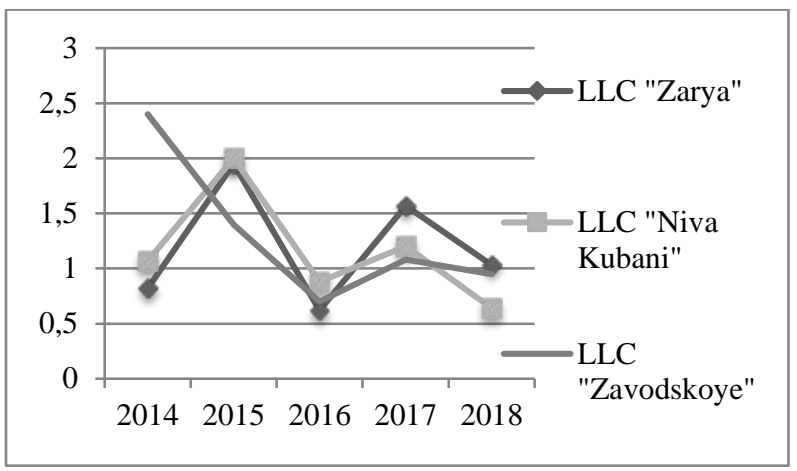

Figure 1 The Growth Rate Revenue

The exceeding of the Growth Rate Revenue happens only with LLC «Zavodskoe», it is 2,4.

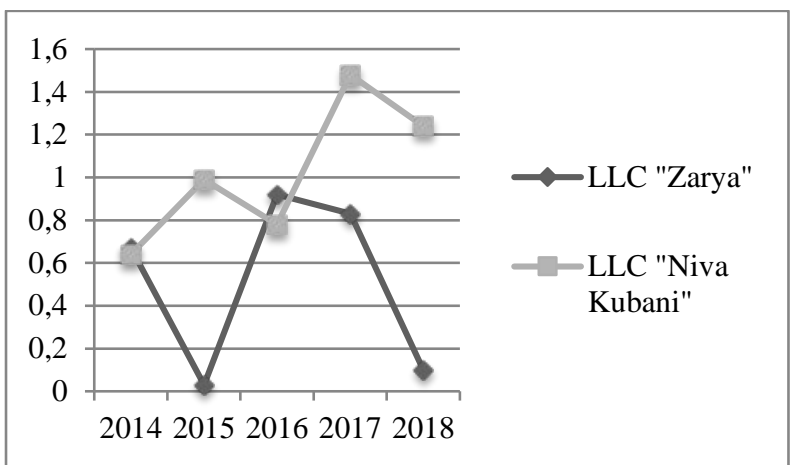

Figure 2 The Growth Rate of Assets Quality

Regarding the Growth Rate of Assets Quality, its value did not diverge significantly and was around 1 . (figure 2) The calculation of the Growth Rate of Assets Quality in LLC «Zavodskoe» is impossible because it has on its Balance Sheet only Fixed Assets and nothing more.

Furthermore, regarding the Growth Rate of the share of Gross Profit in Revenue (figure 3), all the values vary nearby 1 except OOO Niva Kubani with the value of 2,99 in 2015.

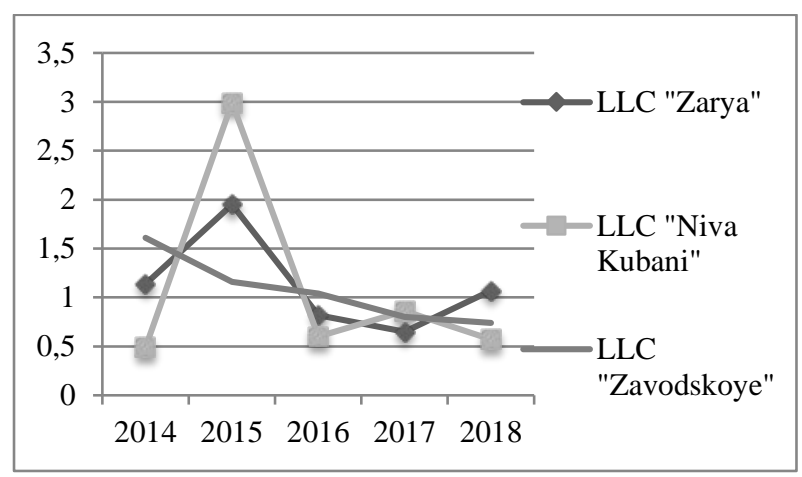

Figure 3 The Growth Rate of the share of Gross Profit in Revenue

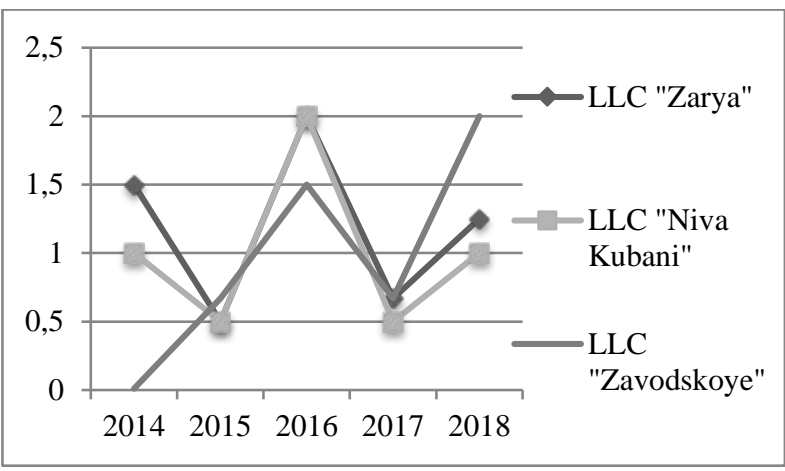

Figure 4 The Growth Rate of Turnover of Account Receivable

Variations of the Growth Rate of Turnover of Account Receivable in all three firms were within 1 (figure 4).

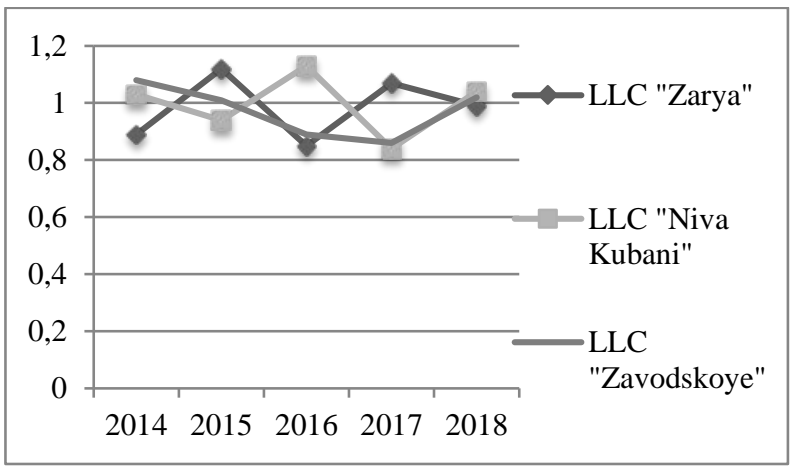

Figure 5 The Growth Rate of shares of Depreciation Assurances

Amortization in analyzed firms was growing fairly equally what can be seen in Figure 5. The similar situation is also observed in the Growth Rate of shares of Expenses in Revenue (figure 6).

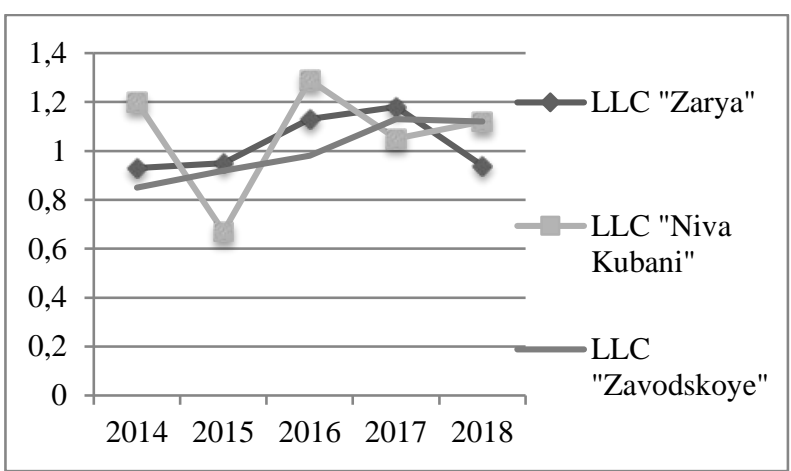

Figure 6 The Growth Rate of shares of Expenses in Revenue

Finally, such indexes as the Growth Rate of Assets Quality, the Growth Rate of Turnover of Account Receivable, the Growth Rate of the share of Gross Profit in Revenue and the Growth Rate of shares of Depreciation Assurances are within a norm and do not diverge from 1. 
A deviation of the Growth Rate is observed in the next cases:

- in LLC «Zavodskoe» the Growth Rate Revenue reached 2,4 in 2014 what, as a result, overcame a norm on 1,4

- $\quad$ in LLC «Niva Kubani» the Growth Rate of the share of Gross Profit in Revenue amounted 2,99 exceeding 1 on 1,99 points. Therefore, a detailed analysis is required to be done detecting potential falsifications.

\section{DISCUSSION}

The practical importance of the done research allows applying the developed methodology in a corporate accounting detecting all misstatements and falsifications. The achieved results can be used not only by internal accounting departments of economic entities but also taught at Universities or on vocational trainings.

The developed procedure is not limited for the future development and, as usual, has its drawbacks. Thus, a current unstable economic situation in Russia may affect on deviations of the Growth Rate of Revenue and Account Receivable. Besides, significant deviations may be observed in newly formed firms.

\section{CONCLUSION}

The authors have developed a methodology of the Financial Reporting evaluation, based on the analysis of the Growth Rate deviations of the absolute and relative indicators for detection of potential falsification of the Financial Reporting. The foundation of the procedure was represented by «Beneish' model» based on the analysis of financial indicators grouped in the aggregated M-score index.

A novelty of the research is based on the development of a method using financial indexes applied in the Russian reporting practice. The author's input consists of a description and testing of the given methodology based on the financial reports on the three agrarian firms in the period of 5 years.
Further research can be intertwined with a development of methodological and organizational measures deepening the analysis of deviating from a norm indexes.

\section{REFERENCES}

[1] Y.I. Sigidov, A.I. Trubilin, E.A. Oksanich, Accounting (financial) reports, Moscow, Infra-M, 2013, pp. 58-60.

[2] N.A. Prodanova, N.S. Plaskova, N.G. Bochkareva, I.A. Babalykova, Yu.Yu. Gazizyanova, O.N. Zherelina, Integrated corporate reporting as an innovative business reporting model, 2019, 8(5), pp. 2075-2078.

[3] M.A. Korovina, T.A. Zaremuk, Detection of falsification of accounting (financial) reporting, Bulletin of Academy of knowledge, 2019, 5 (34), pp. 105-110.

[4] P.P Baranov, A.A. Shaposhnikov, G.V. Maksimova, Fadeykina N.V., Scientific basis of the audit theory, Journal of advanced research in law and economics, 2017, 8(4), pp. 1073-1087.

[5] S.A. Roshchektayev, U.Y. Roshchektayeva, Detection of falsification of financial statements: Beneish' model, Southern Institute of Management Nugal Bulletin, 2018, 2, pp. 37-43. DOI: https://doi.org/10.31775/2305-3100-2018-2-37-43

[6] N.V. Feruleva, M.A. Stefan, Detection of falsification of financial statements in Russian companies: Benish and Roxas model applicability analysis, Russian Management Journal, 2016, 3, pp. 4970. DOI:

https://doi.org/10.21638/11701/spbu18.2016.303

[7] I.V. Safonova, A.D. Silchenko, Falsification of financial statements: concept and tools of identification, Account, analysis, audit, 2018, 6, pp. 37-49. DOI: https://doi.org/10.26794/2408-9303-2018-5-6-37-49 